DOI: $\underline{10.35619 / \text { iiu.v1i10.173 }}$

Марчук Галина

старший викладач кафедри педагогіки і психології (дошкільної та корекційної) імені проф. Т.І. Поніманської

Рівненського державного гуманітарного університету, м. Рівне, Україна

ORCID: 0000-0002-4907-5340

e-mail: galyna.marchuk@gmail.com

\title{
ПІДГОТОВКА МАЙБУТНІХ ВИХОВАТЕЛІВ ДО ФОРМУВАННЯ СОЦІАЛЬНОГО ДОСВІДУ ДІТЕЙ ДОШКІЛЬНОГО ВІКУ
}

Анотація. У статті окреслено актуальність проблеми формування соціального досвіду дітей дошкільного віку в умовах сьогодення. Зміни, що відбуваються в суспільстві, суттєво впливають на процес формування соціального досвіду у дітей дошкільного віку. Дошкільний вік $є$ найважливішим етапом у розвитку особистості дитини. Саме в цей період дитина починає освоювати соціальний світ, вчиться взаємодіяти з людьми, проходить перші кроки в своєму соціальному розвитку. Від того, які цінності будуть сформовані у дітей сьогодні, від того, наскільки молоде покоління буде готове до нового типу соціальних відносин, залежить розвиток нашого суспільства і в теперішній час, і в майбутньому. 3 огляду на це особливої значущості набуває проблема становлення соціального досвіду дітей дошкільного віку. Оскільки на сучасному етапі розвитку освіти мають місце суперечності між процесом формування соціально-активної особистості та умовами ії соціалізації, то перш за все доцільно посилити увагу до підготовки майбутніх вихователів. Зосереджена увага автора на необхідності підготовки майбутніх вихователів до успішної реалізації процесу соціалізації особистості дошкільного віку. Розкрито компоненти готовності майбутніх вихователів до формування соціального досвіду дітей дошкільного віку, виокремлено педагогічні умови для покращення стану готовності майбутніх вихователів до формування соціального досвіду дітей дошкільного віку.

Ключові слова: соціалізація, соціальний досвід, професійна підготовка вихователів, діти дошкільного віку.

Постановка проблеми. Перспективні тенденції розвитку українського суспільства напряму пов'язані з розвитком особистості та індивідуальності кожної людини. Система освіти посилює увагу до особистості як активного суб'єкта життєдіяльності, до демократизації, гуманізації та індивідуалізації навчально-виховного процесу в закладах дошкільної освіти. Модернізація освіти однією з основних цілей передбачає виховання підростаючого покоління, яке здатне до співробітництва, відрізняється мобільністю, динамізмом, конструктивністю. Сучасна система дошкільної освіти потребує оновлення змісту і створення нових освітніх технологій, орієнтованих на соціалізацію дитини та становлення ії особистості. Суспільство, яке ввійшло в період переоцінки базових цінностей, ставить нові вимоги до процесу соціалізації особистості.

Незважаючи на численність наукових напрацювань із проблеми соціалізації особистості дитини, залишаються недостатньо вивченими особливості й основні напрями діяльності закладів дошкільної освіти щодо формування в дітей старшого дошкільного віку соціального досвіду як важливого складника соціального розвитку дитини; не розроблено методики, спрямованої на оволодіння дітьми соціальним досвідом. Отже, сучасні умови породжують низку суперечностей між: суспільною потребою покращення соціального виховання дітей дошкільного віку і недостатньою 
ефективністю суспільного виховання в цьому процесі; між необхідністю формування в дошкільників соціального досвіду та відсутністю методики забезпечення.

Аналіз освітньої практики дозволяє констатувати наявність проблеми забезпечення закладів дошкільної освіти вихователями, які володіють на досить високому рівні вміннями формування соціального досвіду у вихованців. Виникає необхідність формування у майбутніх педагогів закладів дошкільної освіти професійнопедагогічних знань, вмінь, навичок для становлення соціального досвіду дітей.

У зв'язку з тим, що професійна діяльність педагога закладу дошкільної освіти $€$ цілісним процесом і забезпечується не окремими предметними знаннями, а їх системою, виникає необхідність інтеграції підготовки майбутніх вихователів до формування соціального досвіду вихованців 3 навчальними предметами, впровадженими в зміст професійної підготовки студентів педагогічного вузу.

Аналіз останніх досліджень 3 проблеми. Теоретичний аналіз наявних досліджень українських і зарубіжних науковців останніх років показав, проблемі професійної підготовки вихователів закладів дошкільної освіти присвячені наукові роботи Л. Артемової, Г. Бєлєнької, Е. Бєлкіної, А. Богуш, Н. Бібік, Н. Гавриш, І.Дичківської, Л. Коваль, Р. Кондратенко О. Кононко, К. Крутій, І. Рогальської, Т. Поніманської, Н. Кічук, Н. Лисенко, Н. Манжелій, Т. Науменко, В. Пабат, Л. Покроєвої, О. Поліщук, Т. Танько, та ін.

Особлива увага відводиться майбутнім педагогам дошкільної освіти (вихователям, методистам, педагогам додаткової освіти). Це обумовлено унікальністю періоду дошкільного віку і тими завданнями, які вирішує на сьогоднішній день сучасна дошкільна освіта. Необхідність акцентувати увагу на підготовці педагога дошкільної освіти пов'язана 3 тим, що саме в закладах вищої освіти здійснюють підготовку фахівців до безпосередньої роботи з дітьми (Богініч, 2009).

Різноманітні аспекти проблеми висвітлено у філософських та психологопедагогічних дослідженнях в галузі соціалізації особистості: положення про діалектичний характер соціальних відносин (Г. В.-Ф. Гегель), положення про роль діяльності в формуванні особистості (Л. Виготський, О. Леонтьєв), психологопедагогічні концепції розвитку індивідуальності (Л. Виготський, С. Рубінштейн, К. Ушинський); психолого-педагогічні дослідження дитинства як частини соціальної структури суспільства, педагогічні умови збагачення дитячої субкультури на етапі дошкільного дитинства та молодшого шкільного віку, формування соціальних уявлень, методи впливу на становлення позитивних взаємин однолітків (В. Абраменкова, I. Звєрєва, А. Капська, І. Кон, О. Кононко, С. Куліковська, С. Литвиненко, А. Мудрик, I. Рогальська (Печенко), В. Ямницький та ін.); дослідження соціально-педагогічних особливостей системи «дитина-суспільство» (Д. Ельконін, С. Козлова, О. Кононко, Т. Поніманська).

Концептуальні засади щодо професійної підготовки майбутніх фахівців дошкільної освіти в закладах вищої освіти представлені в Законах України «Про освіту» (2017), «Про внесення змін до Закону України» Про вищу освіту» (2014), Державної національної Програми «Освіта» («Україна XXI століття») (1993), національній доктрині розвитку освіти України в XXI ст. (2001), «Про дошкільну освіту» (2001), Базовому компоненті дошкільної освіти (2012), Національній програмі «Діти України» (1996).

Мета статті - розкрити особливості підготовки майбутніх вихователів до формування соціального досвіду

Виклад основного матеріалу дослідження. Проблема підготовки майбутніх вихователів до педагогічної діяльності висвітлена в дослідженнях 3 дошкільної педагогіки та психології провідних вчених Л. Артемової, Є. Барбіної, А. Богуш, Н. Грабовець, С. Кулачківської, Т. Поніманської, І. Рогальської.

У «Великому тлумачному словнику сучасної української мови» (2004, с. 679) поняття «підготовка» трактується як дія за значенням «підготовити»; запас знань, 
навичок, досвід і т. ін., здобутий у процесі навчання, практичної діяльності. У науковопедагогічних дослідженнях диференціюються поняття «готовність» і «підготовка». Тому, готовність традиційно тлумачать як результат процесу підготовки, а підготовку - як процес, під час якого формується готовність особистості до діяльності. Проте, як синонім, уживається паралельно з поняттям «готовність» термін «підготовленість». I знову науковці тут послуговуються принципом диференціації: стан психологічної готовності - це тимчасова готовність, а підготовленість особистості - довготривала готовність.

Термін «професійна підготовка» у «Педагогічному словнику» (Гончаренко, 1997, с. 262) тлумачиться як сукупність спеціальних знань, умінь і навичок, якостей особистості, трудового досвіду і норм поведінки, що забезпечують можливість здійснення успішної праці за обраною професією.

Сьогодення висуває нові вимоги до дошкільної освіти загалом та до кожного вихователя зокрема. Педагоги мають бути творчими особистостями, новаторами ідей, постійно підвищувати свій професійний рівень. Розвиток педагогічного колективу залежатиме від здатності розв'язувати професійні та особистісні проблеми кожним учасником педагогічного процесу. Усвідомлення самого себе, виявлення особистісного начала через колективну співпрацю стимулює перехід до «простору спроможності» розв'язувати різноманітні проблеми (Капська, 1998, с. 67).

Вищесказане набуває значущості, коли йдеться про вплив вихователя на особистість у дошкільному дитинстві, що посідає особливе місце у педагогічній і психологічній науці і трактується науковцями як «період первинного фактичного становлення особистості». Соціалізація особистості в дошкільному дитинстві $\epsilon$ пріоритетним напрямом дошкільної освіти, важливим системним педагогічно виваженим процесом, пролонгованим у часі, у змістовному та технологічному аспектах, що дозволяє дитині прилучатися до соціокультурного процесу та освоювати позицію суб'єкта соціального життя (Рогальська, 2008).

На сучасному етапі розвитку освіти доцільно посилити увагу до підготовки майбутніх вихователів. Саме їм належить виконати завдання, що їх ставить суспільство перед сучасними закладами дошкільної освіти, зокрема: формування фізично здорової, гармонійно розвинутої особистості з високими морально-етичними якостями розвиток, іiі здібностей, нахилів, інтересів, що дасть змогу виконувати функції носія культури, активного суб'єкта соціальних відносин, здатного до навчання в освітніх закладах, подальшого саморозвитку та самореалізації. Виконання таких завдань потребує потужних змін у підготовці вихователів для закладів дошкільної освіти, зосередження уваги на озброєнні їх необхідними знаннями і вміннями.

Задекларовані в державному стандарті дошкільної освіти завдання стосовно формування в дитини необхідної до віку компетентності підвищили вимоги до рівня кваліфікації сучасного вихователя, визначили своєрідне соціальне замовлення суспільства у вищій школі та закладі дошкільної освіти в аспекті підготовки малюка до майбутнього повноцінного життя.

Зазначимо, що в практиці вищих педагогічних навчальних закладів робота, спрямована на формування в дошкільників соціального досвіду, проводиться недостатньо. Аналіз галузевих стандартів вищої освіти фахівців дошкільного профілю, навчальних планів спеціальності «Дошкільна освіта», навчально-методичних посібників, наукових досліджень із зазначеної проблеми дозволяють стверджувати те, що професійна підготовка майбутніх вихователів до проведення роботи щодо соціалізації дитини нині здійснюється лише в межах окремих розділів фахових методик.

3 огляду на такі спостереження, вважаємо, що сучасний освітній простір потребує науково-теоретичного обгрунтування соціально-педагогічного супроводу соціалізації особистості у дошкільному дитинстві та розробці методичних засад його забезпечення у закладах дошкільної освіти. 
Нова соціокультурна ситуація неминуче задає нові параметри перебігу соціалізації, пред’являючи до іiї суб'єкта підвищені вимоги у формуванні нових моделей соціальної поведінки, конструюванні персональної системи цінностей, внаслідок чого перед педагогічною наукою постає потреба переосмислення й перегляду засад виховання та соціалізації особистості у дошкільному дитинстві.

Супровід соціалізації особистості передбачає необхідність сформованого у педагогів цілісного уявлення про дитину як об'єкт і суб'єкт соціалізації, що вимагає визначення специфіки діяльності фахівців закладу дошкільної освіти на кожному віковому етапі іiї соціального становлення, ставлення до неї як до суб'єкта спілкування, співпраці, партнерства, надання права на власний вибір.

Це дозволило нам виявити відсутність чіткої системи у плануванні відповідної роботи з соціалізації дошкільників, недостатню сформованість знань, умінь і навичок студенів для ефективної соціалізації дошкільників, що й слугувало нам виокремленню низки педагогічних умов для вирішення цієї проблеми.

3 метою покращення стану готовності майбутніх вихователів до формування соціального досвіду дітей дошкільного віку ми сформулювали такі педагогічні умови:

- оволодіння студентами знаннями й уміннями, які передбачають інтеграцію дитини у соціальне середовище;

- формування практичних умінь i навичок студентів здійснювати процес формування соціального досвіду дітей дошкільного віку, а також основ гармонійного світосприймання;

- оволодіння уміннями самостійно здобувати знання.

До структури готовності майбутнього педагога дошкільної освіти ми включити такі п'ять складових:

1. Мотиваційний компонент (професійна спрямованість майбутніх вихователів ЗДО до формування соціального досвіду старших дошкільників, сформованість мотивів, потреб у їх використанні);

2. Змістовий компонент (опанування педагогічними, методичними, теоретичними і практичними знаннями 3 формування соціального досвіду та їх використання в освітньому процесі закладу дошкільної освіти);

3. Операційний компонент (сформованість у майбутніх педагогів дошкільної ланки освіти педагогічних та методичних умінь і навичок щодо формування соціального досвіду старших дошкільників);

4.Рефлексивний компонент (сформованість мотивів, потреб у застосуванні рефлексії на заняттях, опанування психолого-педагогічними, методичними знаннями, уміннями, навичками $з$ рефлексії та іiі застосування в освітньому процесі закладу дошкільної освіти під час занять, обізнаність щодо вікових та індивідуальних особливостей старших дошкільників);

5. Інтеграційний компонент (обізнаність щодо власних і потенційних можливостей старших дошкільників у процесі становлення їх соціального досвіду; здатність створювати індивідуально прийнятну методику формування соціального досвіду у дітей старшого дошкільного віку).

Компонентами системи професійно-педагогічної підготовки майбутніх вихователів до формування соціального досвіду дошкільників $є$ мета, функції, структура, зміст, форми і методи іiі реалізації, контроль. Рівень їх розробленості, взаємодії один з одним в результаті реалізації цієї системи визначає ефективність підготовки спеціалістів.

Висновки і перспективи подальших розвідок. Новий підхід до формування системи професійно-педагогічної підготовки майбутніх вихователів стосовно формування соціального досвіду дошкільників зорієнтований на оволодіння студентами знаннями й уміннями, які передбачають інтеграцію дитини у соціальне середовище, що забезпечується структуруванням змісту навчальних дисциплін, спрямованого на утвердження світогляду майбутніх вихователів. 
Перспективу подальших наукових розвідок вбачаємо в розробці моделі та технологій підготовки майбутніх вихователів до формування соціального досвіду дітей дошкільного віку.

\title{
СПИСОК ВИКОРИСТАНИХ ДЖЕРЕЛ
}

Богініч, О., Борисова, 3. та Загарницька І. [ред.] (2009). Підготовка вихователя до розвитку особистості дитини в дошкільному віці: монографія. Київ: Вид-во НПУ імені М. П. Драгоманова, 310 с.

Бусел, В. ред., (2004). Великий тлумачний словник сучасної украӥнської мови. Київ, Ірпінь: Перун, 1440 c.

Гончаренко, С. (1997). Украӥнський педагогічний словник. Київ: Либідь, 376 с.

Капська, А. ред., (1998). Деякі особливості формування готовності студентів до професійної творчості. Моделювання виховної діяльності в системі професійної підготовки студентів: теорія, практика, програми. Київ: ІЗМН, 192 с.

Рогальська, I. (2008). Соціалізація особистості у дошкільному дитинстві: специфіка, сутність : монографія. Київ: Міленіум. 400 с.

\section{REFERENCES}

Bohinich, O., Borysova, Z. \& Zaharnytska I. [red.] (2009). Pidhotovka vykhovatelia do rozvytku osobystosti dytyny $v$ doshkilnomu vitsi: monohrafiia [Preparing an Educator for the Development of a Child's at Preschool Age: monograph]. Kyiv: Vyd-vo NPU imeni M. P. Drahomanova, 310 s. (in Ukrainian)

Busel, V. red., (2004). Velykyi tlumachnyi slovnyk suchasnoi ukrainskoi movy [Great Explanatory Dictionary of Modern Ukrainian]. K., Irpin: Perun, 1440 s.(in Ukrainian)

Honcharenko, S. (1997). Ukrainskyi pedahohichnyi slovnyk [Ukrainian Pedagogical Dictionary ]. Kyiv: Lybid, 376 s. (in Ukrainian)

Kapska, A. red., (1998). Deiaki osoblyvosti formuvannia hotovnosti studentiv do profesiinoi tvorchosti [Some Features of Formation of Students' Readiness for Professional Creativity]. Modeliuvannia vykhovnoi diialnosti v systemi profesiinoi pidhotovky studentiv: teoriia, praktyka, prohramy. Kyiv: IZMN, 192 s. (in Ukrainian)

Rohalska, I. (2008). Sotsializatsiia osobystosti u doshkilnomu dytynstvi: spetsyfika, sutnist : monohrafiia [Socialization of Personality in Preschool Childhood: Specificity, Essence: Monograph]. Kyiv: Milenium. 400 s. (in Ukrainian)

\section{PREPARATION OF FUTURE PRESCHOOL TEACHER FOR THE FORMATION OF SOCIAL EXPERIENCE IN PRESCHOOL CHILDREN}

\author{
Halyna Marchuk \\ Senior Lecturer at the Department of Pedagogy \\ and Psychology (Preschool and Correctional) \\ named after Professor T.Ponimanska, \\ Rivne State University for the Humanities, \\ Rivne, Ukraine \\ ORCID: 0000-0002-4907-5340, \\ e-mail: galyna.marchuk@gmail.com
}

\begin{abstract}
This article highlights the important issue of the pre-school children's social experience formation in modern conditions. Current social changes influence greatly the process of the social experience formation of pre-school children. Pre-school age is the most important stage in personal development of a child. It is now when a child starts to evaluate the social world, learns to interact with other people, and makes the first steps in social development. Current and future development of the whole society depends on the values that children have now and their readiness to enter a new type social relationship. Considering the mentioned above, the problem of the pre-school children's social experience
\end{abstract}


development is very important. The nursery school must form the components of social experience during the pedagogical process. On the one hand, it will help to perform the holistic and systemic approach to child's development, on the other hand - it will correlate the life and development. Modern stage of education is characterized by the contradictions between the process of the formation of a socially active personality and the conditions of socialization, thus it becomes vitally important to improve the future kindergarten teachers' education. The author emphasizes that it is important to prepare the future kindergarten teachers to perform successfully the process of the pre-school personalities' socialization. The author describes the components of the future kindergarten teachers' readiness to form the pre-school children's social experience; the author also specifies the pedagogical conditions to improve the readiness of the future kindergarten teachers to form the pre-school children's social experience.

Keywords: socialization, social experience, vocational training of preschool teachers, pre-school children.

Стаття надійшла до редакиії 10.10.2019 p. 